The Paradox of Perception and Knowledge of Flood Victims towards Flood Causes.

${ }^{* 1}$ M.S. Shaharudin

Development Planning and Management Department,

School of Social Scienes,

Universiti Sains Malaysia, msdin@usm.my

${ }^{2}$ Nik Norulaini Nik Ab Rahman

Biology Department,

School of Distance Education,

Universiti Sains Malaysia, norulain@usm.my

${ }^{3}$ M.I. Syakir

Environmental Technology Department,

School of Industrial Technology,

Universiti Sains Malaysia,

misyakir@usm.my

${ }^{4}$ M. Tajul Arifin

Islamic Finance Department,

School of Management,

Universiti Sains Malaysia,

tams@usm.my,and

${ }^{3}$ Mohd Omar Ab Kadir

Environmental Technology Department,

School of Industrial Technology,

Universiti Sains Malaysia,

akmomar@usm.my

*Corresponding Author 


\title{
The Paradox of Perception and Knowledge of Flood Victims towards Flood Causes
}

${ }^{* 1}$ M.S. Shaharudin, ${ }^{2}$ Nik Norulaini Nik Ab Rahman, ${ }^{3}$ M.I. Syakir, ${ }^{4}$ M. Tajul Arifin, ${ }^{3}$ Mohd Omar Ab Kadir

${ }^{1}$ Development Planning and Management Department, School of Social Scienes, 11800 Universiti Sains Malaysia,
${ }^{2}$ Biology Department, School of Distance Education, 11800 Universiti Sains Malaysia,
${ }^{3}$ Environmental Technology Department, School of Industrial Technology, 11800 Universiti Sains Malaysia
${ }^{4}$ Islamic Finance Department, School of Management, 11800 Universiti Sains Malaysia

*Correspondence Author: msdin@usm.my

\begin{abstract}
This study aims to unravel the paradox of perceptions and knowledge of the flood victims towards the causes of the disaster in both internal and external context. Internal context comprises of a comparison of perceptions and knowledge based on individual characteristics (age, gender, education and income). Whereas, the external context includes the factors of the awareness of the victims towards the amount of rainfall, the impact of land use changes as well as the negligence of the responsible parties. The main objective of this study is to determine the differences of perception and knowledge of December 2014 flood victims in Kelantan towards the factors that lead to the flood. This disaster had resulted in huge amount of money loss as well as traumatize the victims in which can be felt to this day. Since that incident, there were various points of view and different perceptions in finding the cause of the disaster occurred. Besides that, the study found that the level of perception and knowledge as to the cause of the disaster is different in the internal context (individual characteristics). This difference has a significant influence on the awareness of the causes of the floods that occurred in the external context. Significant relationships at the level of $\mathrm{p}<0.05$ has existed between perception and knowledge of the causes of the disaster victims affected by environmental changes in the last 10 years. This indicates that although the victim is aware of the physical environment changes happening around them, but all that is seen as not a major contributing factor to the cause of the floods in Kelantan in 2014.
\end{abstract}

Keywords: Floods, victims, perception and knowledge, individual characteristic 


\section{Introduction}

The floods that hit several states in the east coast of Malaysia at the end of December every year, especially in Kelantan have invited various reactions. The authority/ responsible bodies are respectively pointing fingers in blaming each other. Since that issue arises, there were various reactions and speculations arose in finding the cause of the major disaster occurred. The floods that hit Kelantan state were familiar to people in the state. Kelantan and several states in the east coast are annually prone to flood but what sets it apart is the impact of the floods, scale of the severity, big or small, as well as long or short, in term of the period of time. This condition actually had given a direct impact on the population, especially in Kelantan during the arrival of the Northeast Monsoon season. The monsoon wind that hit the east coast states regularly occurs around October to December each year.

However, what is intriguing in finding the cause of the flood is the perception and knowledge of the flood victim regards to the causes of this disaster happened. According to Gandure et al. (2013) and Geoff and Sarah (2016), although the perception of the population has a strong influence on the range of environment, socio economic and socio political but these perceptions are not permanent, it is changeable according to the time period. Perception and knowledge are two-dimensional, which have very different levels of assessment. A good and comprehensive understanding towards the knowledge could make a person's perception become valuable and precious. In contrast, the perception of a general nature without leaning with sufficient and solid knowledge has been put in a situation that prone to misinterpretation (Krishanti et al., 2011; Peter et al., 2016; Shavit, 2013). Referring to the floods that had occurred in Kelantan at the end of 2014, the majority of victims see the floods as the worst ever that happened in the past 10 years. The incident has indeed given a distressing trauma for most of the population as they had lost their homes, jobs, property, livestock and cut off contact with the outside. The experiences of dealing with the situation due to severity of the flood where they suffered from scarcity of food supply has worsen their agony. However, this study attempts to determine the extent of dimensional perception of the causes of the flood victims in line with their knowledge of the causes of flooding.

\section{Paradox of perceptions and knowledge}

Perception and knowledge are two concepts that complement each other. Even age, gender, education, income, religion, interests, place of residence and source of information are often seen as contributing factors in assessing the perception and knowledge in particular (Peter et al., 2016). There are hundreds of studies proved that individual's knowledge is greatly affects the perception, however even one's argumentative perception still is not sufficient to portray a person is knowledgeable enough about the phenomenon (Roser et al., 2014; Peter et al., 2016). According to Shavit et al., (2013), individual and social perception is also influenced by environmental changes, whether they occur directly or indirectly. Normally, individual and social perception (the victim) would try their best to link the phenomenon to changes that occurred in their environment (Roser et al., 2014). All perception is associated with the sense of identity with the place (topohilia). This situation shows the complexity of the victim's perception is strongly influenced by physical environment, including the social, cultural and cognitive (Peter et al., 2016; Prati et al., 2012). However, the collective dimension of individual perception is seem to represent a dimension of social perception (Roser et al., 2016; Shavit et al., 2013). In other words, both individual and social dimension have led to the cognitive processes that 
influence the behavior of individuals in particular the effective of involvement in dismantling the causes of the phenomenon (Gandure et al,. 2013).

Description and discussion above clearly shows that perception and knowledge are significant in dismantling the cause of a phenomenon. Both the evaluation processes, but without the support of evidence, individually perception and knowledge can become doubtful (Jing Liu et al., 2010). In past experiences, matters in concern, information from third parties, the role of media or technology and become too emotional in feelings have strongly influenced the perception of the individual (Gandure et al., 2013; Peter 2016). Perception also contributes to the style of thinking whether one is optimistic, analytical, critical, objective, negative, logical, proactive, passive and etc. These entire individual thinking qualities will encourage one individual to prove the causes of phenomenon occur from the effect of the changes in their environment (Jing Liu et al., 2010)

Thus, the victim's experience of the flood disaster has created a unique knowledge for the victim to estimate the time when the disaster will occur. However, the scopes of the perception of the victims are still in search for the factors that contribute to the occurrence of floods, yet not to be answered. It is well known that the concept of the knowledge base is a result of what is known by someone. The basic concept of knowledge is strongly influenced by the question of "what". This issue has brought basic input in generating the desire to know by an individual. Knowledge is also seen as a response to one's mental direct experience that gives a logical teaching because something that happens whether it is noticed or unintended. There are several classifications of knowledge often debated by most researchers, especially in the field of environmental psychology are to be acknowledged, understood, applied, analyzed, synthesized and evolved (Donald 1979 ; Krishanti et al., 2011; Shavit 2013). All these have contributed to classification adaptation process knowledge to changes in their environment such as consciousness, interest, evolution, trial and adaptation.

\section{Realities, perceptions and knowledge of the flood victims towards the causes of flood}

Reality, perceptions and knowledge are the three aspects that are complementary and have deliberation towards evaluation of the phenomenon. In order to explain the relationship of these three aspects, a study and observation towards the factors that influencing/ contributing towards the causes of the flood argued should be evaluated and reconsidered. According to Donald (1979), Jing Liu et al., (2010) and Shavit (2013), perception of people living in a particular place for a long period of time, included the evolution of history, can be considered as a diagnosis of the environmental reality of the past about the location, allowing direct comparison between past and present to be made. Thus, it will make the knowledge of the victims to be empowered and remains reality on the ground.

\section{i) Flooding causes and logging and agricultural activities in Kelantan rural areas}

The study conducted by Youngkook (2016), Phong and Rajib (2011) shows that even people living in the same physical environment, but the assessment of the population to the stability or the environment changes greatly influenced by subjective evaluation of different people. They also reflect the relationship of the physical environment and the built environment has a strong 
significant relationship. This is in line with agricultural projects, logging and plantations implemented by corporate and state government, which has shown how changes in the physical environment occur, the impact of policy development agricultural land for crop Latex Timber Clone (TLC), especially in the northern part of the state. Although these projects have gone through the process of Environmental Impact Assessment, the assessment is thought to contribute to the major flooding in state of Kelantan in 2014. This major flooding was very formidable, PKSK (2015) has considered it as equivalent as the big flood occurred in 1967.

Various responses and negative perceptions have pointed fingers at logging, plantations, agriculture and quarrying which were very active over the past 5 years as the cause (outside the control of the authorities). In addition, the effects of selected logging and plantation development activities have been manipulated. Propaganda media and other stakeholder groups have seen areas such as Tanah Tinggi Lojing, Gua Musang, Lebir river, Galas and areas bordering Pahang and Terenganu as the area that caused of the flood. According to the Center for Strategic Studies Kelantan (PKSK), logging activity in the area of Lojing had been frozen since 2006. In fact, the report also pointed out that the system of logging in Kelantan had in fact complied with the annual quota covering 5,960 hectares that approved by the National Land Council. Besides, forest management in Kelantan has been certified in Malaysia Criteria and Indicators for Forest Management Certification Scheme (MTCS). All the development project of Latex Timber Clone (TLC) requires approval of Environmental Impact Assessment prior the opening. However, given the strong perception that associates relation to logging and agriculture is an undeniably difficult, because according to them, the reality on the ground shows the contrary.

\section{ii) The approval of the EIA document is rising sharply}

It can be observed that trend of the EIA approval document from the year 2000 until 2014 has rising sharply. The number of the approval granted was 222 reports up to date. This number also shows 100 percent increment for the projects that have passed the EIA. The focus of the projects that had received EIA approval is plantations, re-plantation of agriculture project and logging. All of these projects are related with the opening of the TLC project area especially in the northern state of Kelantan. Therefore, this situation shows that the state government was committed to the development of agricultural projects especially in some areas in rural Kelantan. As a result, it has been given a negative perception when many catchment areas and forest reserves have been explored in order to achieve those objectives. In reality, changes in the physical environment could be seen clearly, and this has given clear feedback that the greed of the project has invited the cause floods in December 2014.

\section{iii) Factors Climate Change: Extraordinary Quantity Of Rain}

In addition, there are also opinions that argue about the extraordinary quantity of rain is not the driving cause of flood. However, scientific studies that had been made by Strategic Studies Center of the State shows a comparison with the Drainage and Irrigation Department (DID) between 1967 and 2014 in some areas of major rivers (Table 1): 


\begin{tabular}{clll}
\hline No & Main Rivers & Year 1967 & Year 2014 \\
\hline 1 & Sungai Galas, Dabong & $44.51 \mathrm{~m}$ & $46.47 \mathrm{~m}$ \\
2 & Sungai Kelantan, Tangga Krai & $33.61 \mathrm{~m}$ & $34.17 \mathrm{~m}$ \\
3 & $\begin{array}{l}\text { Sungai Kelantan, Jeti Kastam Kota } \\
\text { Bahru }\end{array}$ & $6.22 \mathrm{~m}$ & $7.03 \mathrm{~m}$ \\
\hline
\end{tabular}

Table 1 Amount of rainfall during the worst flood in 1967 and 2014

The consecutive of three days of heavy downpour in Gua Musang from 21 to 23 December 2014, was recorded as high amount of rainfall of $1295 \mathrm{~mm}$ which was equivalent to 64 days of normal rainfall. This situation has been known as the phenomenon of December 23, 2014. The rainfall record at Gua Gagau, Gua Musang on December 23, 2014 was 515m. This is an unusual phenomenon compared to the same date in Kuala Krai (Dabong $154 \mathrm{~mm}$ and Tualang $164 \mathrm{~mm}$ ). The heavy rain has poured large amount of water into the river of Sungai Pertang and Sungai Badong which it had created an occurrence of strong and fast currents (due to large quantities of water from the top of the mountain). It did not only hit the plot but also the valleys and plains habitation. Additionally, it had also hit the entire Lebir River Valley (abundant throughout the Gua Musang) followed by the main river of Kelantan River that begins in Kuala Kerai [PKSK 2015].

\section{iv) The Absent Physical Construction}

The events of heavy rainfall and swift river currents have also been linked with the topography and the lack of physical construction which can act as a buffer. This is because there is no large reservoir area along the river flows of Sungai Lebir and Sungai Galas. Apparently, there is no lake or structure like large water storage reservoirs that comparable with Lake Pergau in Jeli, appears along these rivers flow (before entering the groove of Sungai Kelantan). Thus, when the floods hit Kelantan at the end of December, 2014, it involves all regions, except Bachok and Pasir Puteh where the effect was too small/little when the first wave of flood struck. Meanwhile, Gua Musang, Kuala Krai and Pasir Mas can be deemed relatively large flood as some parties had classified it as a disaster (as there is a huge amount of damage that it had caused) (Mohd Hariri et al. 2015).

\section{Methodology}

This study used a quantitative approach. A total of 500 head of household as despondences (flood victims) from 14 villages were directly involved in this study by using questionnaires. The selection head of household through random number sampling. The selection of the study area have been through the list of names of villages found in 222 EIA documents approved in DOE of Kelantan State during the period 2000 to 2014 . These villages are located within $5 \mathrm{~km}$ from agriculture and logging project site. These villages that have been selected were among the villages that were badly affected by floods in December 2014. The types of village that were involved were a traditional village, organized village, temporary settlements, native village as 
well as FELDA and FECRA land schemes. Analysis of descriptive and inferential was used for comparison determining the dimensional of perception and knowledge of the flood victims towards causes of the flood.

\section{Result}

\section{i) Victims Perceptions vary according to individual characteristics}

The individual characteristics are among the internal factors referring to individual personality, character traits that distinguish one from another (DBP 2013; Kasimah 1997). The term characteristic actually comes from the Greek " karasso " which means, " to mark " the mark or engrave that focuses the application of good values in the form of action or behavior (Agni 2013). Siti Irene Astuti (2010) also saw a character as of its own nature, its own qualities, moral strength or form of behavior that is found in individual groups.

Robyen (2005), Yuliana and Felix (2012) in discussing the individual functions in the form of characters have reflected how the personal characteristics which basically involves gender, skills, knowledge, age and physical condition, of some individuals convert commodities to function capabilities based on their own abilities. In other words, personal character converted commodity character into the function (the ability of individuals). The characteristics of the environment may enhance or inhibit the capability function by its environmental conditions such as geographic location, climate, clean air, etc. (Phong \& Rajib 2011). The results of this study have shown that the perception of victims is different according to the individual characteristics. Income, age, gender, education, income, marital status, descent and occupation of an individual are among the elements that make up the characteristic.

\begin{tabular}{llll}
\hline No. & Individual Characteristic & $\mathbf{x}^{\mathbf{2}}$ value & p value \\
\hline 1 & Age & 19.898 & $0.006^{*}$ \\
2 & Gender & 0.343 & 0.558 \\
3 & Education & 26.097 & $0.00^{*}$ \\
4 & Income & 7.164 & 0.067 \\
5 & Marital Status & 3.518 & 0.318 \\
6 & Descent & 80.463 & $0.00^{*}$ \\
7 & Occupation & 10.585 & 0.102 \\
8 & Colony Location & 20.822 & $0.00^{*}$ \\
\hline
\end{tabular}

* significant level $\mathrm{p}<0.05$

Table 2 Chi squared test between Individual characteristic and cause flooding

Table 2 clearly shows that the individual's perception towards the flooding causes as a result of agricultural development projects, plantations, logging and mining are vary based on the different individual characteristics. Results are seen in parallel with the study by Yuliana and Felix (2012), which argued that the characteristics of individual differences not only lead to the potential difference psychologically, but also build a variety of perception through the changes in their environment. All this will happen as long as the individual is aware of the changes that 
occur and impact on their daily functions. The study found that age, education level, ethnicity and place of residence have significant relevance to the level of $p<0.05$ while gender, income, marital status and occupation had no significant relationship at the level of $p<0.05$. These results indicate the victim of various villages have different perceptions of the causes of the floods based on individual characteristics of the victim.

\section{ii) Significant relationships knowledge of victims with sensitivity to environmental changes}

The results showed that the majority of victims admitted that agricultural development projects, plantations, logging and mining that occur in their environment strongly influence the physical and environmental changes with a significant relationship at the level of $p<0.05$. The study also found that the perception of the victim in responding to change in their environment closely related to the knowledge among the population regarding the impact of development projects with changes that had occurred. In line with the argument Tara et al. (2011) and Krisanthi et al. (2010), it is noticable that among the victim has become distinct at the environmental changes surrounding them, thus establishment of more effective environmental management system into a more sustainable direction. Table 3 shows that there is a significant correlation between the existence of agricultural projects, plantations, logging and mining with the changes in their environment. That is the strength of the relationship that exists around 0.44 until 0.59 . This indicates that the development project also affected the daily life of the changing environment.

\begin{tabular}{llcc}
\hline No. & Changes & $\begin{array}{r}\text { Relatio } \\
\text { n Strength }\end{array}$ & $\begin{array}{c}\text { p value/ significant } \\
\text { level }\end{array}$ \\
\hline 1 & The daily movement of people & 0.562 & $0.00^{*}$ \\
2 & Housing environment & 0.567 & $0.00^{*}$ \\
3 & Recreation and leisure environment & 0.447 & $0.00^{*}$ \\
4 & Public transportation services & 0.439 & $0.00^{*}$ \\
5 & Infrastructure facility & 0.527 & $0.00^{*}$ \\
6 & Source of income & 0.597 & $0.00^{*}$ \\
7 & Job opportunities & 0.591 & $0.00^{*}$ \\
8 & The number of people who migrate & 0.551 & $0.00^{*}$ \\
9 & Household income & 0.587 & $0.00^{*}$ \\
10 & The level of health of the people & 0.573 & $0.00^{*}$ \\
\hline
\end{tabular}

Table 3 The relationship strength between the environmental changes and flooding causes

\section{iii) Victim's knowledge about the flood risk is low}

The study also shows that the level of knowledge on disaster risk is very low among the villagers. Studies conducted by Youngkook (2016), Phong and Rajib (2011) shows that there are positive and strong relationships between their built environment and the natural environment. In line with the study results, found that although more than two thirds of victims (Felda Chiku 7; Felda Aring 1 \& 2; Kg. Meranto; Kg Lambok; Kg. Bekok; Kg Perasu) were aware of the existence of projects plantation, agriculture and logging around them in a large scale, only $19 \%$ of the total respondents stated that the development projects were among the contributing cause to the floods occurred in December 2014. The test results show the value of chi-square (x) 36 
459 , which is a high-value $\mathrm{x} 2$, is significant at the level $\mathrm{p}<0.05(\mathrm{p}=0.00)$. This situation shows that most of the victims from various locations in the district of Gua Musang and Kuala Krai were very aware of the existence of land development projects in their environment, however just a minority of them have deemed such activities as non-contributors to the problem of flooding which occurred in December 2014.

\section{iv) The changes of physical environment is most felt by the victims}

Majority of the victims saw changes in river, followed by rolling hills and forest reserves and existing plantations as the most significant changes in the physical environment in the past five (5) to ten (10) years. The study conducted by Krisanthi et al. (2010), Phong and Rajib (2011) also proved that exploration of the physical environment without proper planning and sustainable management of the environment has revealed an absolute disaster and destruction. The study also showed that the information from the victims and surveys in the field have found these changes included high sediment content in water, shallow depth and width of the narrow river and also the hills became bald and barren. In addition, the processes of re-planting on a larger scale makes environmental change increasingly apparent. Table 4 shows the changes in land use that occurred about 10 years ago until now.

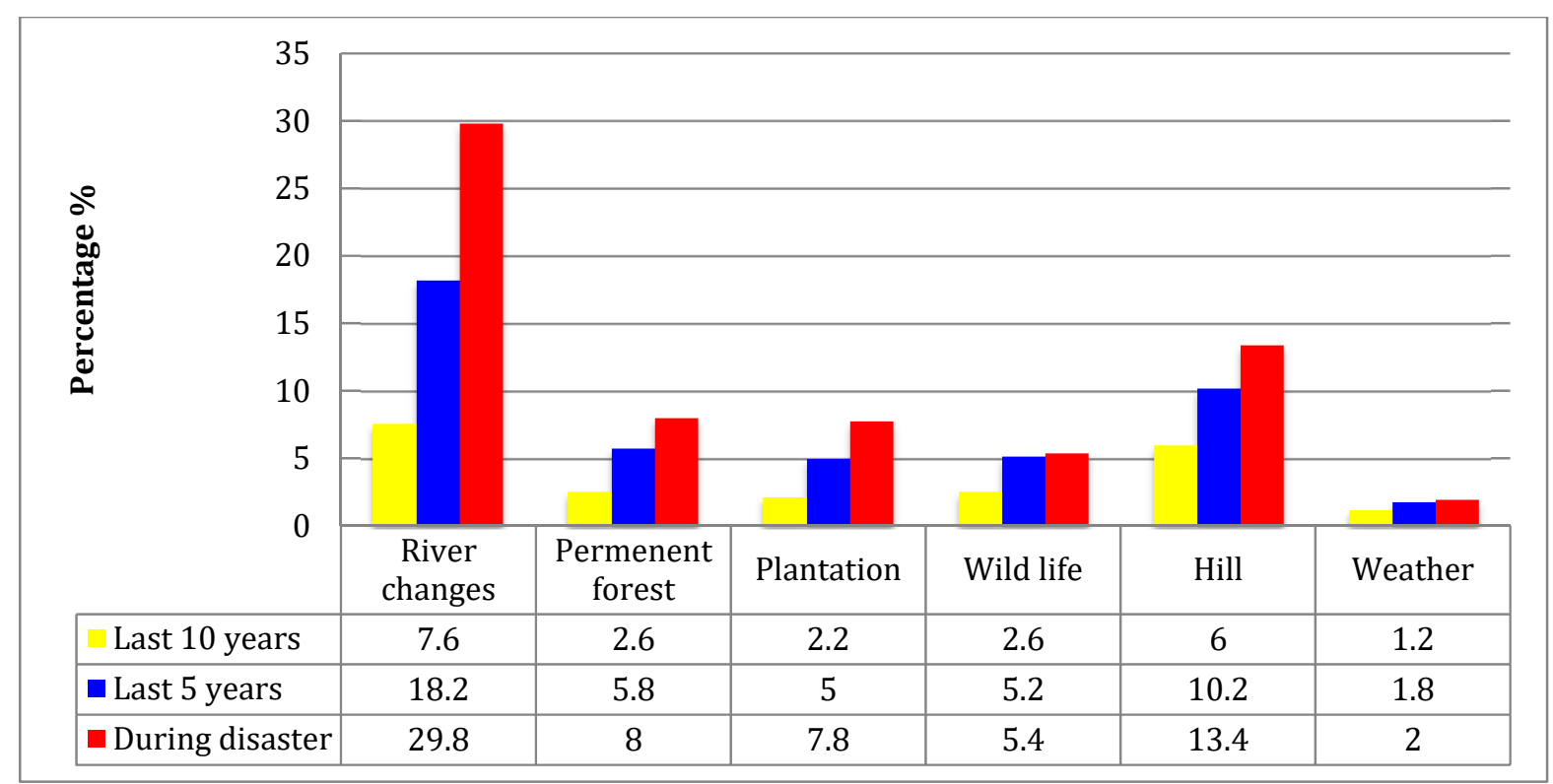

Graph 1 Physical Environmental Changes

\section{Conclusions}

The dimensional comparison of perception and knowledge that causes the disaster also explains the strength of the victim to adapt to an environment of critical or vulnerable towards disasters. The unbalanced perception and knowledge toward a disaster had put psychological responses among the victims, which tend to blame the stakeholders than the cause of natural events (Krisanthi et al., 2010). This misunderstanding occurs when the victims failed to understand the 
reality of the disaster. The study also proved that the critical factor, when victim's knowledge was obscured towards impact of environmental changes that occur in their environment in the flood disaster. The ability to adapt to the environment is also seen as a critical contributor to the conflict compatibility level of perception and knowledge of the causes of the disaster by the victims.

The significant difference between victims' perception and knowledge of the causes of the flood are influenced by individual characteristics. Individual characteristic has strengthened victim's mentality through their subjective assessment on the environmental changes. Subjective evaluation is often present in different forms since it is bound by age, gender, employment status, income, and location of residence, or in other words through a factor in the season.

The level of perception and knowledge of the victim was also influenced by external factors. Victims who are vulnerable to disasters also tend to build speculation of sources of information available. However, due to gridlock knowledge to understand the cause of the flood scientifically as the amount of rainfall, the impact of land use changes as well as the negligence of those responsible have put the victim's psychology tends to formulate something using a critical and negative thought. However, the study looked at the preparation and explanation consistently or periodically by the stakeholders would be able to reduce the gap between perception and knowledge of the victims of a phenomenon (Krisanthi et al., 2010). It would ultimately help them to understand the causes of disasters proactively and effectively.

\section{Acknowledgements}

This research is conducted by using the research funding of the TRGS/1/2015/USM/01/4/5 project.

\section{References}

Agni. 2013. Definisikarakter, available at: http://pustaka.padani.web.id/2013/03/pengertiankarakter.html. (acsessed 13 January 2016)

Angela Pennisi di Floristella. (2015), "Dealing with natural disasters", The Pacific Review 2015: $1-24$.

DBP. 2013. Kamus Dewan (Edisi 4). Kuala Lumpur: Dewan Bahasa Dan Pustaka.

Donald Appleyard. (1979), " The Environment as a Social Symbol: Within a Theory of Environmental Action and Perception", Journal of the American Planning Association 45 (2): 143-153.

Geoff A. Wilson \& Sarah L. Dyke. (2016), "Pre- and post-installation community perceptions of wind farmprojects: the case of Roskrow Barton", Cornwall, UK. Land Use Policy 52: 287296. 
Jing Liu, ZhiyunOuyang\& Hong Miao. (2010), "Environmental attitudes of stakeholders and their perceptions regarding protected area-community conflicts: A case study in China", Journal of Environmental Management 91: 2254-2262.

Kamisa, Drs. (1997), Kamus Lengkap Bahasa Indonesia. Surabaya: Kartika.

Krisanthi Seneviratne, David Baldry \& Chaminda Pathirage. (2010), "Disaster knowledge factors in managing disasters successfully", International Journal of Strategic Property Management 14 (4): 376-390

Mohd Hariri Arifin, Mohd Nawawi Mohd Nordin \& Azimah Hussin. (2015), "Penilaian geofizik dan geologi bagi penentuan lokasi terbaik telaga tiup sebagai sumber air altenatif pasca banjir, (in) Mohd Ekhwan Toriman, Mohd Khairul Ambri Kamarudin, Hafizan Juahir, Muhammad Barzani Gasim, Azizah Endut, Azman Azid \& Roslan Umar (Editors)", Bencana Banjir: Kupasan Pelbagai Perspektif, p.p. 125-142. Kuala Terengganu: Penerbit Universiti Sultan Zainal Abidin.

Natalia Pirani Ghilardi-Lopes, Alexander Turra, Marcos S. Buckeridge, Amanda Cristina Silva, Flavio Augusto de Sauza Berchez \& Valeria Marques de Oliveira. (2015), "On the perceptions and conceptions of tourists with regard to global environmental changes and their consequences for coastal and marine environments: Acase study of nortrh Sao Paulo State coast, Brazil", Marine Policy 57: 85-92.

Peter Emmanuel Cookey, Rotchanatch Darnswasdi \& Chatchai Ratanachai. (2016), "Local people's perceptions of Lake Basin water governance performance in Thailand", Ocean \& Coastal Management 120: 11-28.

Phong Tran \& Rajib Shaw. ( 2011), "Towards an integrated approach of disaster and environment management: A case study of Thua Thien Hue province, central Viet Nam", Environmental Hazards 7 (4): 271-282

Pelan Kajian Strategik Kelantan (PKSK). (2015), "Flood study in Kelantan", Portal Kerajaan Negeri Kelantan, available at: http://ebanjir.kelantan.gov.my (acsessed 20 January 2016)

Robeyns, I.( 2005), "The capability approach: a theoretical survey", Journal of Human Development 6 (1): 93-114.

Roser Rodriguez-Carreras, Xavier Ubeda, Luis Outeiro \& Francesc Aspero. (2014), "Perceptions of social and environmental changes in a Mediterranean forest during the last 100 years", The Gavarres Massif Journal of Environmental Management 138: 75-86.

S. Gandure, S.Walker \& J.J.Botha. (2013), "Farmers' perceptions of adaptation to climate change and water stress in a South African rural community", Environmental Development 5: 39-53. 
Siti Irene Astuti. (2010), "Pendekatan holistic dan kontekstual dalam mengatasi krisis karakter di Indonesia", Cakrawala Pendidikan XXIX: 41-58.

Tal Shavit, Shosh Shahrabani, Uri Benzion \& Mosi Rosenboim. (2013), "The effect of a forest fire disaster on emotions and perception of risk: A field study after the Carmel fire", Journal of Environmental Psychology 36: 129-135.

Tara O'Connor Shelley, Ted Chiricos\& Marc Gertz. (2011), "What about the environment? Assessing the perceived seriousness of environmental crime", International Journal of Comparative and Applied Criminal Justice 35 (4): 307-325.

Youngkook Kim. (2016), "Impacts of the perception of physical environments and the actual physical environments on self-rated health", International Journal of Urban Sciences 2016: $1-15$.

Yuliana Polishchuk \& Felix Rauschmayer. (2012), "Beyond "benefits"? Looking at ecosystem services through the capability approach", Ecological Economics 81: 103-111. 